\title{
Cities and Violence: An Empirical Analysis of the Case of Costa Rica
}

\author{
Gregorio Gimenez ${ }^{1}$ \\ Liubov Tkacheva ${ }^{2}$ \\ Katarína Svitková ${ }^{3}$ \\ Beatriz Barrado ${ }^{4}$
}

${ }^{1}$ Professor of Economics and Business at the University of Zaragoza. Zaragoza, Spain.

E-mail: gregim@unizar.es. ORCID: https:/ / orcid.org/0000-0003-3702-4017

${ }^{2}$ Professor of Psychology at the State University of St. Petersburg. St. Petersburg, Russia.

E-mail: 1.tkachewa@spbu.ru; ORCID: https://orcid.org/0000-0002-9822-1914

${ }^{3} \mathrm{PhD}$ in International Relations at the Faculty of Social Sciences of Charles University. Prague, Czech

Republic.

E-mail: katarina.svitkova@fsv.cuni.cz; ORCID: https:/ / orcid.org/0000-0002-4839-7313

${ }^{4} \mathrm{PhD}$ student in Economics at the Faculty of Economics and Business, University of Zaragoza. Zaragoza,

Spain.

E-mail: beatricevicent@gmail.com; ORCID: http:/ / orcid.org/0000-0003-2033-801X

Database: https://doi.org/10.7910/DVN/3556RW

\section{INTRODUCTION}

The world's urban population is booming; by 2050, six and a half billion people will be living in urban areas (World Bank, 2011a). On the one hand cities are significant population, infrastructure and economy hubs, as well as centers of political power; on the other hand, according to a time-proved assumption provided by the social sciences, the growth of cities tends to lead to disruption and crime (Shaw and McKay, 1942). The focus of this study on the city level is in line with the gradual transformation of governance and the growing importance of urban political economies (Sassen, 2006). In a public policy domain, the urban lens is useful for addressing site-specific issues - especially in the field of security (UN-Habitat, 2012; Jaitman and Guerrero, 2015). Crime rates tend to reveal geographic patterns, with higher concentration in urban areas (Eck and Weisburd, 2015; Johnson et al., 2007; Curman, Andersen and Brantingham, 2015; Gill, Wooditch and Weisburd, 2017). Understanding the degree to which urban concentration affects

DADOS, Rio de Janeiro, vol.64 (1): e20190127, 2021

https://doi.org/10.1590/dados.2021.64.1.225 
crime incidents is a fundamental issue to better plan crime prevention strategies and reduce violence. Focusing on the urban dimension of violent crime, the main aim of this study is to examine the relationship between the degree of urban concentration and the number of serious offenses, particularly homicides.

Most existing research is focused on developed countries ${ }^{1}$ and often has methodological problems, mostly due to the use of databases with poor data quality. This problem is especially acute in developing countries, where crime statistics are usually fragmented, inconsistent, and aggregated only to the most macro levels. The lack of information and the weak national statistic systems are an important challenge for conducting rigorous research. It is important to emphasize that our contribution is not only in terms of providing additional evidence, but also in terms of the type of context that we analyze. As Ajzenman and Jaitman (2016:9) remark, providing empirical evidence from developing countries is crucial, given that "developing and developed countries are different in many dimensions, and also because crime levels tend to be much higher in the developing world and, in particular, in Latin America".

Specifically in Latin America, one of the main characteristics of the phenomenon of crime and violence is the degree of geographic concentration. Urban homicide rates are much higher than the average homicide rate, and almost half of all homicides are concentrated in 10\% of municipalities (IDB, 2017). Violence in cities is not only homicidal and includes all types of crimes. Among the main causes associated with the concentration of crimes in urban areas, Alvarado and Muggah (2018) highlight those linked to the existence of large poor and peripheral neighbourhoods, the presence of disorderly urbanization and youth unemployment.

Regarding our case study, Costa Rica, Vilalta Perdomo, Castillo and Torres (2016) highlight a series of specificities in the link between urbanization and delinquency. They point out that the Costa Rican population is largely concentrated around so-called Gran Área Metropolitana (GAM). They remark that, according to the Instituto Nacional de Estadística y Censos (INEC), in 2011 this area occupied 4\% of the national territory and concentrated $53 \%$ of the population. Most of the country's crimes take place in this area, which is characterized by higher unemployment, but also higher education and income levels. Higher education is related to higher earnings, which means that there 
are more potential victims for crimes against property. The authors also indicate that, within the GAM, San Jose is considered the most important zone of the country for the cocaine trade. Consequently, the GAM as a whole, and San Jose in particular, present the greatest challenges for public policies, especially in relation to urban development and public safety.

Our in-depth econometric analysis of Costa Rica - a country of the Global South with significant urbanization and inequality rates - uses highly disaggregated socioeconomic data. It focuses on a wide range of types of crimes, in combination with econometric techniques which test for the presence of endogeineity, which constitutes a significant empirical contribution to the existing literature.

The article is organized as follows. The next section presents a literature review in the field of urban violence in Latin America and Costa Rica. Its main objective is to provide a general context of citizen insecurity in the region and, particularly, the country, before presenting the case study in the third section. This empirical part develops an econometric model in order to demonstrate the connection between urban concentration and crime, particularly homicides.

\section{URBAN CRIME: CONTRIBUTING FACTORS IN LATIN AMERICA AND COSTA RICA}

Existing research on the relation between cities and security confirms that dense urban areas generally tend to be more violent than small towns or rural areas. This is due to the very nature of cities as points of concentration of population and social interactions, including various types of conflicts. The link between cities and crime has been widely researched in the field of criminology since the early findings of the Chicago school (Shaw and McKay, 1942). As pointed out by Glaeser and Sacerdote, three factors are especially relevant for urban crime: "higher pecuniary benefits, higher chance of avoiding arrest and a concentration of crime-prone individuals in cities" (1999:227). In recent years, the connection between the urban environment and crime has been explored using a variety of methodological approaches and empirical examples from cities all around the world (Ceccato, 2012). Among the characteristics which affect crime rates in large cities, it is customary to allocate social inequality and poverty (Cozens, 2007), especially taking into account its spatial stratification within neighbor- 
hoods (Graif, Gladfelter and Matthews, 2014); social and racial segregation (Jürgens and Gnad, 2002); racial inequality (Beall, Crankshaw and Parnell, 2004); the presence of "hot spots" of crime in different sectors of the city (Goldsmith and McGuire, 2000; CAF, 2014; Weisburd and Amram, 2014; Weisburd, 2015; Gill, Wooditch and Weisburd, 2017); the existence of zones of sufficient socioeconomic deprivation (Martínez Jr., Rosenfeld and Mares, 2008; Shoff and Yang, 2012); and the continually increasing social disparities accompanied by spatial fragmentations within the city (Coy and Pöhler, 2002; Rodgers, 2004).

Throughout the last decades, theoretical and empirical studies have focused on geographic, social and economic aspects of crime in cities². Taking into account globalization and cities' permanent expansion, Oscar Newman developed the theory of "defensible space", which focuses on crime prevention through environmental design (Newman, 1996). A recent body of research in this field, referred to as "new urbanism", has found its way to practical implementation in cities, although its critics have pointed to a lack of evidence of actual crime reduction (Cozens, 2011). Policies based on urban fortifications and their implications in terms of social integration have been critically examined (Landman, 2012). Temporal and seasonal effects on violent crime in cities have also been explored (Ceccato, 2005; Azjenman and Jaitman, 2016).

Bridging theory with methods, spatial and temporal statistical analysis of criminal behavior is of particular relevance for the study of violence in cities (Ratcliffe, 2010). Therefore, a wide-ranging field of geographical criminology has relied on statistical methods to study urban risk, mostly in developed countries. According to Bernasco and Elffers (2010:700), this field of inquiry has brought substantial innovations either methodological or empirical - to the study of violent crime. In this context, our article aims to develop a solid statistical framework to study crime in the Latin American urban context, which requires the clear identification of factors which contribute to delinquency in cities. These factors, analyzed below, will be used as control variables in the model developed in the subsequent section.

Current levels of urban violence in the Global South are considered a serious "threat to public health" (Ceccato, 2014). Thus, according to Bergman (2018), in spite of rapid economic expansion and significant improvements in social benefits, Latin American countries have suf- 
fered unprecedented crime rise and instability, compromising public safety. He highlights the accessibility of illicit financial flows, which is so attractive for many people - including officials -, as the main cause. While the definition, nature, and extent vary between and within countries, Latin America is one of the world's most violent regions, with violence primarily occurring in cities (Human Security in Cities, 2007; UNODC, 2014; Lappi-Seppala and Lehti, 2014; Jaitman and Guerrero, 2015). CAF's (2014) study of the concentration of crimes in Sucre (Venezuela) and four Colombian cities (Barranquilla, Bogota, Cali and Medellin) revealed that $50 \%$ of homicides took place in $1.6 \%$ of the blocks of the cities, and $50 \%$ of thefts and robberies took place in approximately 7\% of the blocks of the cities during 2011/2012. This concentration has been highlighted in other cities from Brazil, Colombia, Mexico, Uruguay, and Venezuela. Using geolocalized data, Ajzenman and Jaitman (2016) have found that $50 \%$ of crimes are concentrated in $3 \%$ to $7.5 \%$ of street segments, and $25 \%$ of crimes are concentrated in $0.5 \%$ to $2.9 \%$ of street segments. According to Gaviria and Pagés (2002:190), the risk of becoming a victim of violent crime increases substantially in Latin American cities with more than a million residents. Even in countries where most of the population is rural, crime tends to concentrate in cities. In Guatemala, $40 \%$ of homicides occurred in the capital city in 2006, which houses only $20 \%$ of the population (Matute and García, 2007 apud World Bank, 2011b).

Although the causes of urban crime can depend on a wide array of explanatory factors, we focus on those related to "demographic" or "social" conditions which provide an environment in which criminal activities are more attractive. Regarding demographic conditions, a population's age structure is typically related to crime rates. According to traditional literature from criminology, both perpetrators and victims of criminal activities are, in the majority of cases, young. Being an immigrant has also been found positively related with crime behaviour (UN-Habitat, 2007:66-71; World Bank, 2011b). Evidence seems to suggest that this may have been an important factor in some Latin American countries (Biderman, Mello and Schneider, 2009). Increases in population, urbanization and density have also been identified as explanatory factors. Different studies have showed that agglomeration of population is positively correlated with crime (Glaeser and Sacerdote, 1999). 
Among socioeconomic conditions, inequality and poverty have been identified as important explanatory factors of crime rates. These factors, clearly visible and inherent to the Latin American region, become especially apparent in dense urban areas. Unequal access to employment, education, health, and basic physical infrastructure, along with the urban poors' living conditions, are closely related to the incidence of crime and violence, especially affecting the poorest (Rodgers, 2004). Moreover, neighbourhoods with a high concentration of economic disadvantages tend to have less social capital and collective efficacy, fuelling the intensification of violence and crime (Sampson, Raudenbush and Earls, 1997; Sampson and Raudenbush, 2001). Studies have supported this relationship, finding meaningful correlations between inequality and several measures of crime rates for different Latin American countries (Fajnzylber, Lederman and Loayza, 2002; Bourguignon, Nunez and Sanchez, 2003; Soares, 2004). Furthermore, a range of other drivers of urban violence have been identified, including public sensitivity to crime, small-arms availability, gang presence, narcotics trade, drugs and alcohol use, inefficient criminal justice systems, low quality urban infrastructure planning, have also been identified as explanatory factors of urban violence (Fay, 2005; UN-Habitat, 2007; Briceño-León, Villaveces and Concha-Eastman, 2008; Jütersonke, Muggah and Rodgers, , 2009; Soares and Naritomi, 2010; Muggah, 2012; PNUD, 2013).

In the case of Costa Rica, violence factors are compatible with those found by similar reports on Latin America. The Ministerio de Salud (2004) includes poverty, inequality, lack of education, urbanization and overcrowding among risk factors. Thus, within the greater metropolitan area of the capital, which continues to expand, risks are even higher. According to the report (Ministerio de Salud, 2004:38), this phenomenon directly contributes to "structural opportunities for homicides". At the same time, problems derived from the social, economic and demographic situation strongly affect residents' mental and physical health, which can also lead to increased rates of violent crime.

According to another study, by the Inter-American Development Bank (2013), the most significant variable with respect to homicide in Costa Rica is inequality - which is the key factor in the econometric model presented in our empirical section. Despite the relevance of variables such as unemployment, poverty and youth population mentioned above, this report does not consider these factors as contributing to increased homicide rates in Costa Rica (IDB, 2013:81). Taking spatial 
location into account, approximately half of homicides occur in places which could be considered as typical for an urban environment, such as streets, sidewalks and public parks (p. 84).

In sum, the references summarized in this section demonstrate a high degree of continuity in terms of context and specific variables related to violent crimes in Latin America - and particularly in Costa Rica. The following section analyzes a considerable volume of highly disaggregated data regarding domestic socioeconomic factors which, based on the concepts referred to in the present section, are widely believed to contribute to violent crime. Controlling for this extensive set of explanatory variables, the results of the analysis support the conclusion that there is a factor, inherent to cities and independent from most studied factors, which leads to increased homicide rates in urban environments.

This empirical work relates to academic and policy-oriented studies cited above, which explore the link between urban concentration, phenomena inherent to urban societies and increased levels of violence. As shown below, there is an empirically robust connection between urban concentration and violence when controlling for a broad set of the causal variables.

\section{Case study}

There are a number of reasons why Costa Rica is suitable for our empirical analysis. First, Costa Rica is located in Latin America, a region where the issue of violence has singular importance in both social and economic terms. In addition, it shares certain endemic characteristics with other countries in the region, such as the presence of transnational organized crime, pronounced inequality and polarization in development between rural and urban areas. The country has experienced an alarming increase in crime rates, especially in the rate of intentional homicides (UNODC, 2019) and in the amount of cocaine confiscation (Unidad de Información y Estadística Nacional sobre Drogas, 2018). In 2005, the number of homicides per 100,000 population was 7.9 (see Figure 1). Between 2005 and 2017, homicides increased by $75 \%$ to reach 13.8 - a huge increase in a region where most countries' figures have been decreasing ${ }^{3}$. The World Health Organization considers rates above 10 as an epidemic. 
Figure 1

Evolution of the homicide rate in Costa Rica (2005-2017)

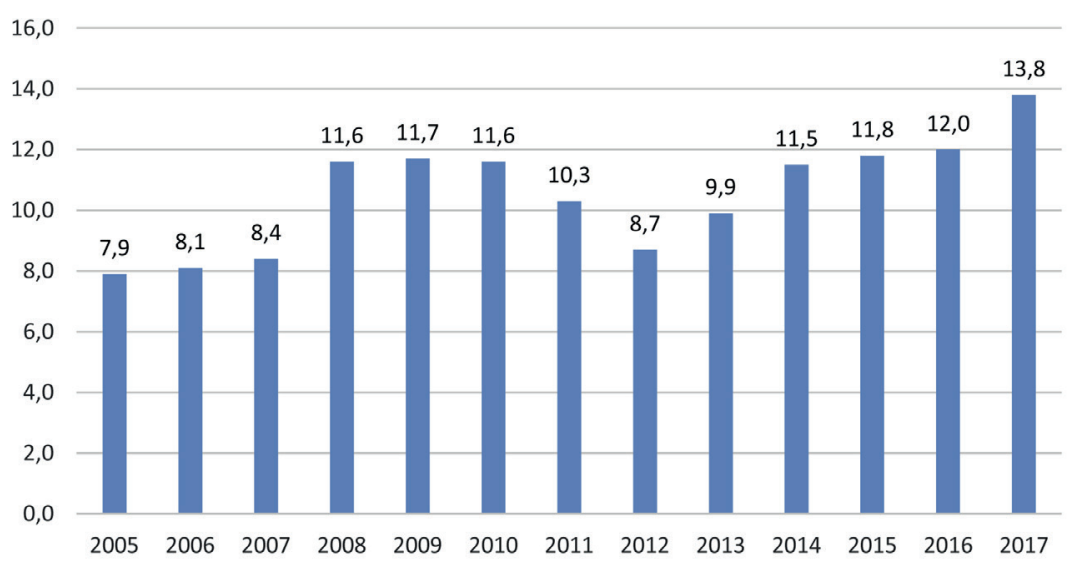

Source: made by the authors, based on data from UNODC (2019).

\section{EMPIRICAL ANALYSIS OF CRIME AND URBAN DEVELOPMENT}

\section{Methodology}

The baseline model of the research can be expressed synthetically as:

$$
V_{i}=\alpha+\beta U_{i}+\boldsymbol{\delta} \boldsymbol{X}_{i}+\varepsilon_{i}
$$

Violence $\left(V_{i}\right)$ in each district $i$ is determined by the degree of urban development $\left(U_{i}\right)$ and a vector $\boldsymbol{X}_{i}$ that contains a broad set of explanatory variables (control variables). The structural parameter $\beta$ determines the effect of urban development on violence. The model is initially estimated with the homicide rate per 10,000 inhabitants as a dependent variable ${ }^{4}$.

Although it is difficult to find an accurate indicator of violence, the homicide rate is the most widely used in the empirical literature. That happens because the legal definition of homicide tends to be more homogenous across countries than that of other criminal offenses, thus facilitating comparison. In addition, its measurement is more accurate, because other offenses, especially misdemeanours, are often not reported to the police for various reasons, such as the costs and hassles inherent to the presentation of complaints and the lack of trust 
in the local police force and/or the judicial system. Subsequently, the estimation results are subjected to a sensitivity analysis in which the homicide rate is replaced by a broad spectrum of criminal variables.

As explained in section 2, which analysed the factors behind crime rates, the model used can be considered a standard model in the literature on violence, and the choice of variables included in the vector $\boldsymbol{X}_{i}$ follows existing empirical research, as justified in the conceptual framework. These variables are: number of police officers deployed per 10,000 inhabitants, population density, annual population growth, proportion of men to women, proportion of immigrants, Gini index of income inequality, poverty index of unsatisfied basic needs, unemployment rate and average schooling years of the population over 15. Despite the common usage of the Gini index as the main measure of inequality, we have considered it appropriate to include, in addition to this variable, a poverty index based on unsatisfied basic needs. The Gini index collects information about how wealth is distributed in an economy, but it does not provide an accurate idea of the population living in situations of exclusion. The Gini index may show an equal distribution of income even in regions with a high level of poverty. Given that inequality and poverty are clearly different concepts and that both variables may affect the rates of violence, they are both incorporated into the model. All variable definitions, sources of data, statistics and correlations are in Appendix A.

Two methodological considerations regarding the baseline estimation are necessary. First, due to data characteristics, the variance of the disturbance is very likely not constant across observations, leading to a loss of efficiency of the estimator. The result of the Breusch-Pagan/Cook-Weisberg test for heteroscedasticity, $x_{(1)}^{2}=70.86$, leads us to reject the null hypothesis of constant variance. Therefore, robust variance estimates and consistent standard errors are reported in the estimations. Second, the inclusion of the police force as an explanatory variable leads us to consider the presence of simultaneity problems between this variable and the homicide rate. In other words, an increase in the police force may lead to a reduction in the number of offenses, but, in turn, the crime rate will condition the number of police officers deployed. This would imply double causality, which could lead to endogeneity concerns in the estimation, resulting in $E\left(\varepsilon_{i} \mid \boldsymbol{X}_{i}\right) \neq 0$. If this were the case, the use of instrumental variables could provide unbiased and consistent estimators, which would be 
more efficient than the ordinary least squares (OLS) estimator. However, in the absence of endogeneity issues, standard errors associated with instrumental variable estimators would be high and, then, the OLS estimator would be more efficient. Therefore, it is crucial to verify the presence of endogeneity in the model. To do so, a Wooldridge test for endogeneity (see Wooldridge, 1995) with the null hypothesis of the variable police force being exogenous is performed. This test uses robust variance estimates and allows for heteroscedastic and autocorrelated errors, which makes it suitable given the characteristics of the data handled. The test is carried out making use of a model with instrumental variables in which a wide set of crimes other than homicides are used as instruments for the number of police officers. These are attacks to residential and non-residential buildings, mugging, robbery (items in vehicles, people, residential and non-residential buildings) and theft (vehicles, people, residential and non-residential buildings). The result of the test, with $x_{(1)}^{2}=0.36$ and $F_{(444)}^{1}=0.35$, leads us to accept the null hypothesis: the number of police officers is exogenous in the model. Consequently, OLS with robust standard errors is a more efficient estimation technique and, therefore, the one that will be used in the estimation.

\section{Effects of urban development on homicide rate}

Table 1 reports the results of the baseline crime model. We begin with a complete set of homicide rate determinants and, later, we investigate the magnitude and stability of the influence of urban development. The first econometric estimation in Column (1) synthesizes the results of our baseline cross-sectional regression using the explanatory control variables in $X_{i}$. This baseline estimate shows that the homicide rate is positively and significantly related to population density, poverty, unemployment and average schooling years - the latter of which we study in more detail later in this section. The number of police officers, the population growth rate and the proportion of men negatively influence the homicide rate, although the relationships are not significant. The proportion of immigrants and inequality, measured by the Gini index, are positively correlated with the homicide rate, without being significant. 
Table 1

Baseline OLS estimates of Costa Rica crime model with urban development (dependent variable: homicide rate)

\begin{tabular}{|c|c|c|c|c|}
\hline & (1) & $(2)$ & (3) & (4) \\
\hline \multirow[t]{2}{*}{ Police force } & $-0,024$ & $-0,034^{* *}$ & $-0,032^{* *}$ & $-0,035^{* *}$ \\
\hline & $(0,016)$ & $(0,016)$ & $(0,016)$ & $(0,018)$ \\
\hline \multirow[t]{2}{*}{ Population density } & $0,128^{* * *}$ & $0,101^{* * *}$ & $0,115^{* * *}$ & $0,112^{* * *}$ \\
\hline & $(0,032)$ & $(0,032)$ & $(0,033)$ & $(0,033)$ \\
\hline \multirow[t]{2}{*}{ Annual population growth } & $-3,835$ & $-5,187^{*}$ & $-6,346^{* *}$ & $-5,398^{*}$ \\
\hline & $(2,987)$ & $(3,009)$ & $(3,054)$ & $(3,030)$ \\
\hline \multirow[t]{2}{*}{ Men } & $-4,308$ & $-2,118$ & $-1,537$ & $-2,397$ \\
\hline & $(5,220)$ & $(5,228)$ & $(5,266)$ & $(5,213)$ \\
\hline \multirow[t]{2}{*}{ Immigrants } & 5,179 & 4,835 & 5,718 & 4,813 \\
\hline & $(3,739)$ & $(3,720)$ & $(3,966)$ & $(3,759)$ \\
\hline \multirow[t]{2}{*}{ Gini index } & 1,546 & 1,834 & 1,249 & 1,664 \\
\hline & $(1,311)$ & $(1,289)$ & $(1,322)$ & $(1,349)$ \\
\hline \multirow{2}{*}{$\begin{array}{l}\text { Poverty index (unsatisfied } \\
\text { basic needs) }\end{array}$} & $2,994^{* * *}$ & $3,300^{* * * *}$ & $3,982^{* * *}$ & $3,410^{* * *}$ \\
\hline & $(0,646)$ & $(0,656)$ & $(0,750)$ & $(0,670)$ \\
\hline \multirow[t]{2}{*}{ Unemployment rate } & $11,463^{* * *}$ & $9,199 * *$ & $7,787^{*}$ & $8,911^{* *}$ \\
\hline & $(4,354)$ & $(4,187)$ & $(4,144)$ & $(4,172)$ \\
\hline \multirow[t]{2}{*}{ Average schooling years +15} & $0,122^{*}$ & 0,048 & $0,303^{* *}$ & 0,067 \\
\hline & $(0,071)$ & $(0,073)$ & $(0,134)$ & $(0,075)$ \\
\hline \multicolumn{5}{|l|}{ Urban Effects } \\
\hline \multirow[t]{2}{*}{ Urban population $\%$} & & $0,797^{* * *}$ & $2,790^{* * *}$ & \\
\hline & & $(0,185)$ & $(0,987)$ & \\
\hline \multirow{2}{*}{$\begin{array}{l}\text { Urban*Average schooling } \\
\text { years }+15\end{array}$} & & & $-0,270^{* *}$ & \\
\hline & & & $(0,125)$ & \\
\hline \multicolumn{5}{|l|}{ Urban category } \\
\hline 1. $<20$ percentiles & & & & (base) \\
\hline \multirow[t]{2}{*}{ 2. $20-40$ percentiles } & & & & $0,301^{* *}$ \\
\hline & & & & $(0,128)$ \\
\hline \multirow[t]{2}{*}{ 3. 40-60 percentiles } & & & & $0,475^{* *}$ \\
\hline & & & & $(0,189)$ \\
\hline \multirow[t]{2}{*}{ 4. $\quad 60-80$ percentiles } & & & & $0,543^{* * *}$ \\
\hline & & & & $(0,190)$ \\
\hline \multirow[t]{2}{*}{ 5. $>80$ percentiles } & & & & $0,692^{* * *}$ \\
\hline & & & & $(0,162)$ \\
\hline \multirow[t]{2}{*}{ Constant } & $-0,091$ & $-1,061$ & $-3,134$ & $-1,013$ \\
\hline & $(2,874)$ & $(2,871)$ & $(3,161)$ & $(2,849)$ \\
\hline
\end{tabular}


Table 1

Baseline OLS estimates of Costa Rica crime model with urban development (dependent variable: homicide rate) (cont.)

\begin{tabular}{lcccc}
\hline & $(1)$ & $(2)$ & $(3)$ & $(4)$ \\
\hline Number of districts & 459 & 459 & 459 & 459 \\
R2 & 0,192 & 0,220 & 0,229 & 0,223 \\
Adjusted R2 & 0,176 & 0,203 & 0,210 & 0,200 \\
\hline
\end{tabular}

Notes: ${ }^{* *} \mathrm{p}<0.01,{ }^{* *} \mathrm{p}<0.05,{ }^{*} \mathrm{p}<0.1$.

Huber-White estimated standard errors are in parentheses below coefficients.

Source: made by the authors, based on the variables explained in the Table A.1 of the appendix.

In Column (2), the percentage of urban population over total population is added to the baseline model as an explanatory variable. Urban areas were defined by the Instituto Nacional de Estadística y Censos with physical and functional criteria, taking into account tangible items such as clearly defined quadrants, streets, sidewalks, urban services (garbage collection, street lighting) and economic activities. This new variable has a very significant and strong relationship with the homicide rate, and its inclusion raises the adjusted $\mathrm{R}^{2}$ from 0.18 to 0.20 . An increase of one standard deviation of the percentage of urban population raises the homicide rate by 0.3 homicides per each 10,000 inhabitants $\left(0.38^{*} 0.8=0.30\right)$. This effect is very strong, considering that the average of 0.78 homicides per 10,000 inhabitants in the country. To understand the importance of this figure, one needs to bear in mind that, for example, the effect of a decrease of one standard deviation in the police force would result in a much lower increase in the homicide rate $\left(4.025^{*} 0.034=0.14\right.$ homicides per 10,000 inhabitants). These empirical findings further support our initial claim, according to which urban environment clearly contributes to elevated levels of violence.

The inclusion of the percentage of urban population in the model does not produce changes in the direction of the relationship of other variables, but the variable of police force becomes significant at $5 \%$, the population growth rate at $10 \%$ and the unemployment rate slightly reduces its significance from $5 \%$ to $10 \%$. It is worth noting that the estimates of the impact of the average schooling years on homicide rates, while always positive, are quite sensitive to the specification and are not significantly different from zero when the percentage of urban population is introduced into the model. The basic model concentrates only on the additive effects of education and urban concentration, but their effects may be complementary. Indeed, the correlation between the two variables is 0.76 . If we add the combined effect of both to the 
regression [Column (3)], through the term Urban*average schooling years +15 , we note that this has a negative sign and is significant, which can be interpreted as: in the districts with the largest urban concentration, more education is accompanied by a decrease in the homicide rate. However, the effect of the individual variable is still positive and significant. Overall, results suggest that education has different effects on crime in urban and rural areas 5 .

To summarize, basic results provide strong evidence in support of a strong link between urban concentration and violent crime. They also comprise the baseline for subsequent analyses of the magnitude and progressivity of the effect. For these analyses, the variable percentage of urban population is transformed into a factor variable, classified into five categories, each of which contains 20 percentiles. Category 1 , which will be the base category, consists of districts whose population is up to $20 \%$ urban ( $28 \%$ of districts). Category 2 is composed of districts whose population is between $20 \%$ and $40 \%$ urban ( $14 \%$ of districts). Categories 3 and 4 represent districts whose urban population ranges from $40 \%$ to $60 \%$ and from $60 \%$ to $80 \%$, respectively ( $14 \%$ and $10 \%$ of districts, respectively). Finally, category 5 comprehends districts in the 80th percentile or higher (which accounts for 35\% of the districts of Costa Rica).

Replication of the basic model with the addition of the factor variable [Column (4)] has almost no impact on the magnitude and significance of remaining explanatory variables. The homicide rate per 10,000 residents progressively increases in districts with the largest urban concentration with respect to the base category. The effect is progressive and highly significant in all categories. The maximum difference is reached in the case of districts between the percentiles 80 and 100 of the urban population: they have an average homicide rate per 10,000 inhabitants, exceeding the rate of the districts with less than $20 \%$ of urban population by 0.69 victims (6.9 per 100,000 inhabitants).

This progressive effect - the greater the urban concentration, the greater the increase in the homicide rate - may also be verified through a series of contrasts for comparing the mean of each percentile group with the mean of all previous groups, after adjusting for explanatory variables. To do this, the following null hypotheses, which assume that there are no statistically significant differences in homicide rate among the five urban categories, are tested: 
$\mathrm{H}_{0}$ number 1: $\mu_{2}=\mu_{1}$

$\mathrm{H}_{0}$ number $2: \mu_{3}=\mu_{<3}$

$\mathrm{H}_{0}$ number $3: \mu_{4}=\mu_{<4}$

$\mathrm{H}_{0}$ number $4: \mu_{5}=\mu_{<5}$

The contrasts carried out are based on the differences from the observation-weighted mean of previous levels. Because each group has different sample sizes, contrasts are performed by weighting the means for each group according to their sample size. Table 2 provides the summary statistics for each of the contrasts. The overall joint test presented at the bottom of the table simultaneously examines all specified contrasts and shows that the adjusted means of most urbanized areas are greater than the means of the areas with less urban concentration. These differences in homicide rates are statistically significant $(\mathrm{F}=$ 4.99). If we focus on each category separately, we can appreciate that the adjusted mean of homicide rates in districts with more than $80 \%$ of urban population is 0.45 units greater than the mean of districts with less urban concentration, and this difference is highly significant. Other contrasts show similar effects, with differences in the means with previous levels of $0.35,0.37$ and 0.30 that are also significant.

Table 2

Contrasts of marginal linear predictions of the equality of the means for each urban group with the mean of all the previous groups

\begin{tabular}{lcccc}
\hline Urban group & $\mathrm{F}$ & $\mathrm{P}>\mathrm{F}$ & Contrast & $\begin{array}{c}{[95 \% \text { Conf. }} \\
\text { Interval] }\end{array}$ \\
\hline$(2$ vs 1$)$ & 5.55 & 0.019 & 0.301 & {$[0.05,0.553]$} \\
& 4.37 & 0.037 & $\begin{array}{c}0.128) \\
0.370\end{array}$ & {$[0.022,0.718]$} \\
$(3$ vs $<3)$ & & $(0.177)$ & \\
& 3.92 & 0.048 & $0.347)$ & {$[0.003,0.692]$} \\
$(4$ vs $<4)$ & & $(0.175)$ & \\
& 10.8 & 0.001 & 0.446 & {$[0.179,0.713]$} \\
$(5$ vs $<5)$ & & $(0.136)$ & \\
& 4.99 & 0.0006 & & \\
Joint & & & \\
Note: Huber-White estimated standard errors are in parentheses below coefficients. \\
Source: made by the authors, based on the variables explained in the Table A.1 of the appendix.
\end{tabular}

Figure 2 is extremely illustrative. It shows each of the contrasts with a confidence interval of $95 \%$. The dashed line at zero indicates the adjusted mean of the groups with less urban population than the one 
being contrasted. The progressivity of the effect can be clearly seen, with the mean of the homicide rate of each group being well above the joint mean of all previous groups.

Figure 2

Contrasts of predictive margins of urban categories with $95 \%$ confidence intervals

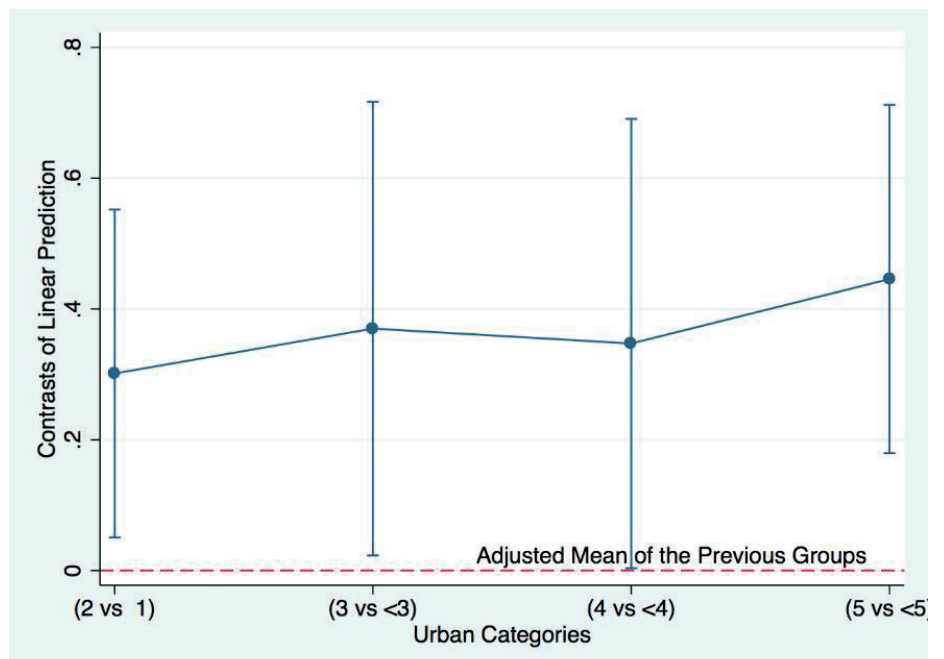

Source: made by the authors, based on the variables explained in the Table A.1 of the appendix.

In sum, we can, therefore, reject all the null hypotheses and maintain that results are consistent with the thesis stating that urban concentration leads to a statistically significant increasing effect in crime.

\section{Effects of urban development on other criminal typologies}

The estimates and statistical contrasts carried out show that urban concentration is a key factor in explaining the homicide rate of Costa Rican districts. Is this causal relationship maintained in crimes other than homicide? Table 3 presents the results of the estimates of the basic model which includes urban categories as an explanatory variable and a wide range of eleven criminal typologies as dependent variables: attacks to residential and non-residential buildings, mugging, robbery (items in vehicles, people, residential and non-residential buildings) and theft (vehicles, people, residential and non-residential buildings). Results suggest that there is no evidence of causality between urban development and crimes other than homicide. 


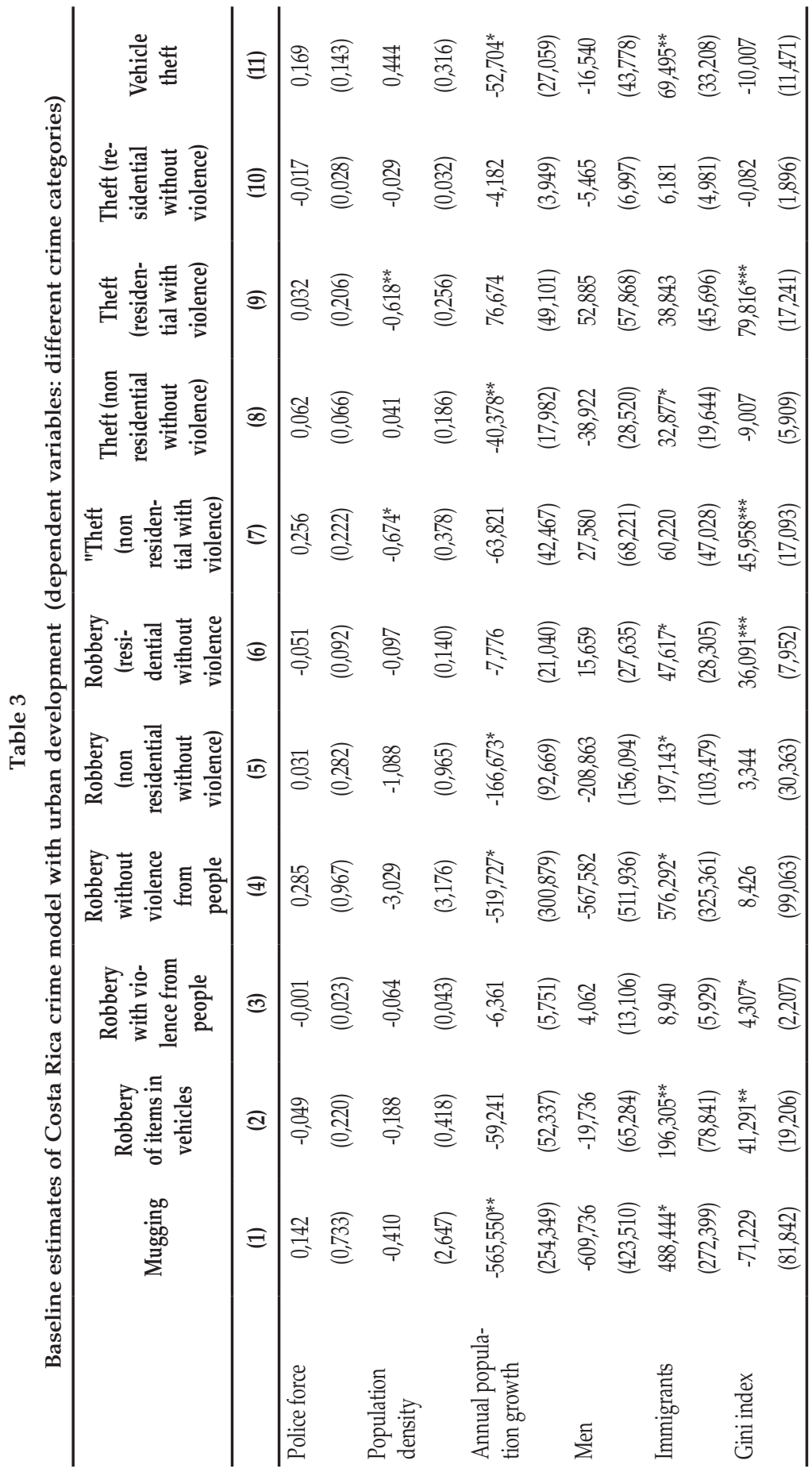




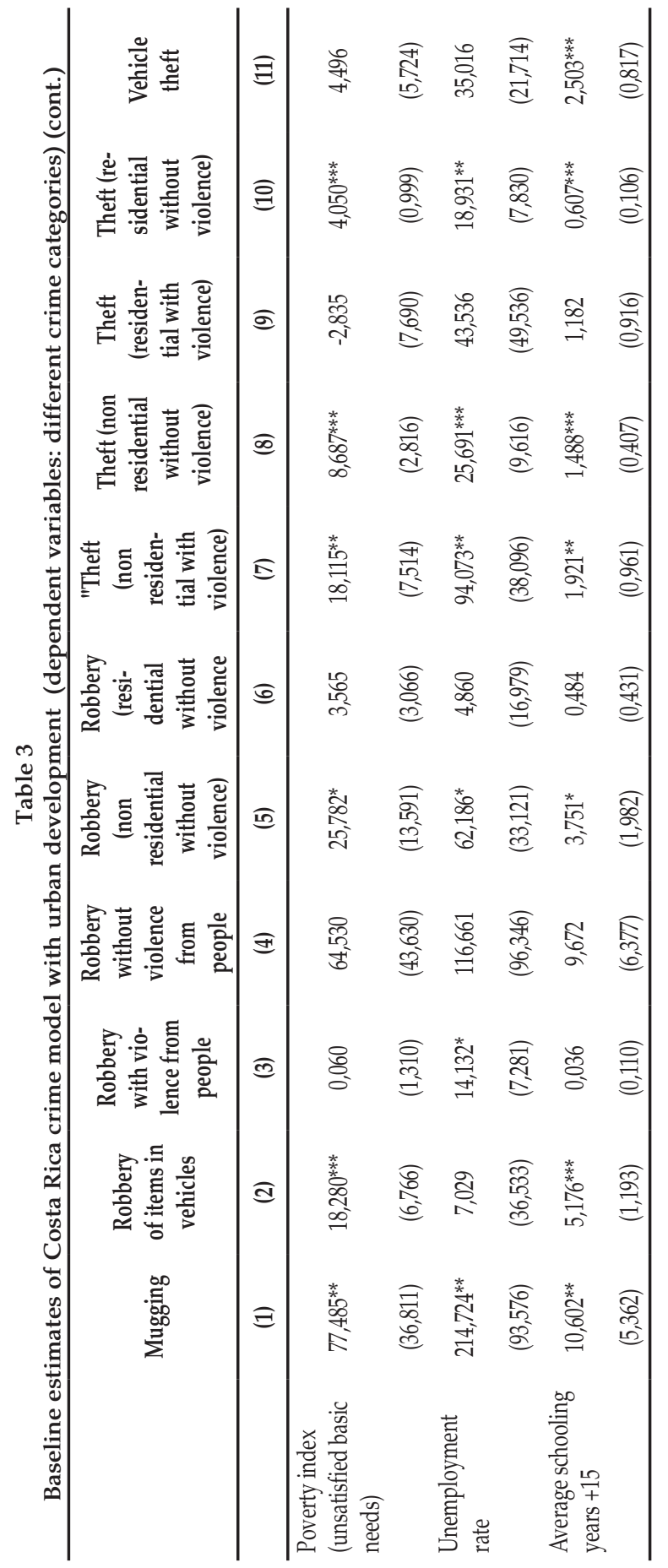




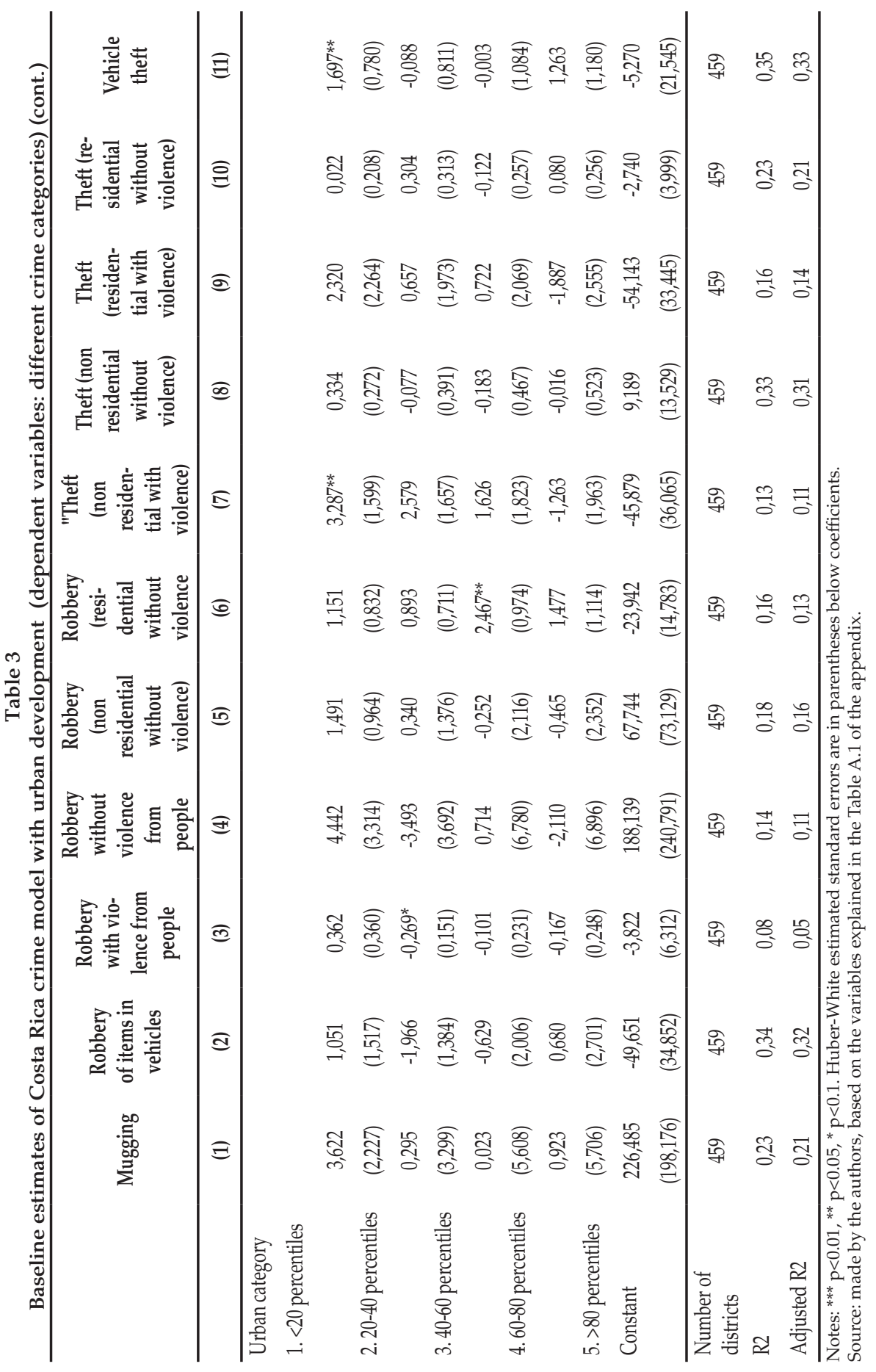


As to why urban development is an explanatory factor for homicides but not for other crimes, it must be pointed out that the correlation between homicides and other criminal typologies is relatively low: between 0.11 and 0.45 (Table 4). That is, there is no clear association between homicide and other crimes, since some homicides occur during other crime events - such as a rape, robbery or burglary - and frequently involve adult or juvenile gang violence, but a significant number of homicides have their origin in other factors - the influence of alcohol or narcotics, disagreements about money, arguments between couples or jealousy are typical causes - and are committed by some of the victim's intimate contacts - friends, boyfriends, girlfriends, spouses or ex-spouses.

Table 4

Correlations between homicide rates and other crime categories

\begin{tabular}{|c|c|c|c|c|c|c|c|c|c|c|}
\hline 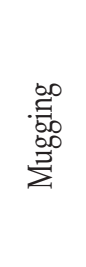 & 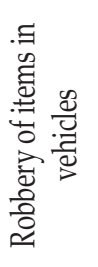 & 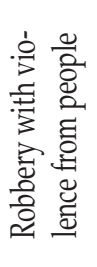 & 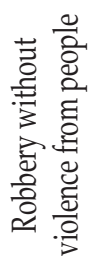 & 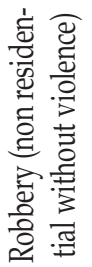 & 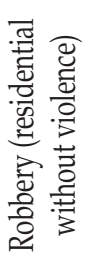 & 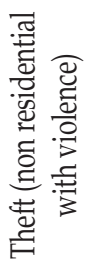 & 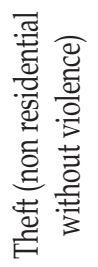 & 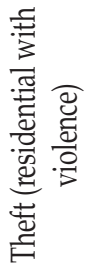 & 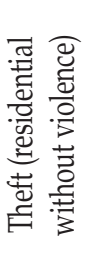 & 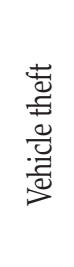 \\
\hline 0,369 & 0,298 & 0,115 & 0,32 & 0,335 & 0,29 & 0,257 & 0,4 & 0,152 & 0,448 & 0,318 \\
\hline
\end{tabular}

Source: made by the authors, based on the variables explained in the Table A.1 of the appendix.

One should also note that the correlation is stronger when more serious crimes - attacks to residential (0.45) and non-residential buildings (0.4) or mugging (0.37) - are computed and weaker in the case of misdemeanours. This lack of association could be caused by measurement errors, of special importance in less serious offenses because, as noted before, these may not be accounted for due to the inconveniences involved in reporting crimes and a lack of trust in police officers and/ or the judicial system. These measurement errors would not allow us to estimate the true impact of urban development on these crimes. This is why the empirical literature often uses homicide rates as dependent variables, since their definition and measurement are more accurate.

\section{DISCUSSION}

It is well known that fast urbanization has put resources and services under great pressure. In developing countries, the urban poor who are able to find work are often bound to spend their lives affected by 
insecurity and insufficiently paid jobs. Rural migrants as well as immigrants often have no other choice than to settle in slum areas of towns and cities, where they experience extreme poverty (Harroff-Tavel, 2010) while burdened with social segregation, isolation, spatial fragmentation and growing vulnerability (Graif, Gladfelter and Matthews, 2014). Adversity is not limited to socioeconomic conditions - this study has focused on the spatial dimension of insecurity, tied to the physical environment of the most vulnerable urban dwellers.

The phenomena mentioned above lead to an increase in crime rates in cities. The results of the present study validate this hypothesis, using highly disaggregated data to trace the occurrence of violent behaviour in all 473 districts of Costa Rica. Controlling for variables usually connected to crime incidents, the correlation between urbanization and homicide is significant and robust. The quality of the data set used for this study, in addition to its specific focus on the role of urbanization in explaining homicide rates, constitute a major contribution to the literature in the field. In sum, results highlight the significance of urban development in explaining crime, measured by homicide rates. We do not find this relation in the case of other offenses. It is clear that, given the current urbanization rate trends in Latin America, the study of the relation between urban environments and violent crime is of great relevance.

The case of Costa Rica can thus be considered an example of what happens in Latin America, one of the most urbanized regions in the world, and its urbanization rates, which overreach $80 \%$ and continue to grow. The variables traditionally measured in relation to - and considered as contributing to - violent crime in Latin America continue to be relevant in local to regional scales. This reinforces the pressing need to address the negative effects of urbanization on cities and citizens throughout Latin America and the importance of sustainable urbanization in designing development and public safety policies.

Our findings are in line with existing literature and similar studies focused on the region. Buvinic and Morrison (2000) find that violence in Latin America is correlated with city size. The authors point out that agglomeration can intensify anti-social behaviour, reducing social cohesion and, hence, increasing crime rates. The urbanization process has also been positively correlated with violence. Gaviria and Velez (2001) examined Colombian cities and found that urban growth 
is positively correlated with crime. In a context of rapid urbanization, the inability of many cities to support the increasing demand for urban infrastructure and public services negatively affects public safety, allowing disorderly urbanization processes, which in turn affects crimes rates. Rivera (2015) examined the sources of crime in 19 Latin American countries over the period 1980-2010. The author finds that positive trends in urban population are correlated with increases in countries' murder rates. As the author explains, opportunities for crime tend to be plentiful in urban areas, since social interaction is more frequent and the risk of punishment is lower than in rural areas. Cardia (2000) shows that the rapid process of urbanization manifested in the headlong growth of cities in Brazil is one of the main factors for the increase in violent crimes. Accordingly, Chon (2011) reveals that high homicide rates of Latin American nations are due to high poverty and income inequality levels, which are also direct consequences of rampant urban growth and lack of resources.

\section{CONCLUSIONS}

Violence in Latin America constitutes a considerable public health problem and has huge social costs. Understanding causes and impacts of violence has become a top priority in order to design violence-prevention programs and to improve living standards. The main aim of this study was to provide a context-specific understanding of violence, paying particular attention to crime in urban areas. We consider this approach especially useful in Latin America, a region notorious for its high homicide rates, where formal and informal urbanization is rather pronounced. The empirical analysis of our case study, using highly disaggregated data on 473 Costa Rican districts, reveals that:

1. The degree of urban development plays a key role in explaining homicide rates, once we have controlled for a wide range of explanatory variables.

2. This effect is progressive: the greater the urban concentration, the greater the increase in homicide rates.

3. This causal relationship between violence and urban concentration is not observed in offenses other than homicide. 
As for this study's limitations, two main issues are mentioned in the analysis. First is the omission of data about transnational organized crime. Although this phenomenon is very significant in the geographical region of Latin America, including this kind of data would overreach the scope of this case study, rather concerned with quantitative data on the domestic level only. Second, the study does not incorporate data about the number of legalized weapons despite its relevance for homicides. The main reasons for this omission are the unavailability of reliable data in this respect and the fact that registering a weapon in a certain district does not limit its use to this particular geographical unit. Furthermore, it is likely that a significant portion of firearms are held illegally, which would further reduce the reliability of such data. Using only incomplete data on the possession of legal firearms would rather distort the model.

Further research in this area might seek to apply this model and this analytical methodology to other countries in Central America, as new databases with crime and socioeconomic variables at this level of disaggregation become available. Researchers typically face great difficulties in accessing rich and complete databases in this region of the world. At the same time, "smart policing" which tries to allocate existing resources more wisely, taking into account available information, has become increasingly important in the fight against crime. This approach relies on an intensive use of statistical data and high-quality criminal analysis, which help to identify areas with larger crime concentration. In this context, the results of the present study show the importance of working with such data, and contribute to a wider understanding of causes and consequences of urban violence.

(Received on December 13, 2016)

(Resubmitted on June 4, 2019)

(Accepted on October 15, 2019)

\section{NOTES}

1. For some exceptions, see Caldeira (2001) and Ceccato (2005).

2. See for example Ceccato (2014).

3. El Salvador, Jamaica, Honduras, Brazil and Guatemala reached the highest homicide rates during 2017 with 60, 55.7, 42.8, 29.7, 26.1 homicides per 100,000 respectively.

4. Homicide rates are usually reported for every 100,000 or 10,000 inhabitants, which is also common in criminology. We chose this latter in order to make the figures of the 
estimated coefficients of the regressions more easily comprehensible (they are visible with 3 decimals). If we worked with homicide data in terms of 100,000 inhabitants, the coefficients of the variables in the tables would be closer to 0.000 . However, following reviewers' suggestion, we have provided statistical figures in terms of homicides per 100,000 inhabitants.

5. Authors like Luallen (2006) have highlighted this kind of relation with empirical research for U.S. schools, concluding that loss of school days (due to teacher strikes) significantly affects youth violence in urban areas, although the impact is irrelevant in rural and suburban areas,. 


\section{REFERENCES}

AJZENMAN, Nicolas; JAITMAN, Laura. (2016), Crime concentration and hot spot dynamics in Latin America. Washington, Inter-American Development Bank. Retrieved from https: / / publications.iadb.org/bitstream/handle/11319/7702/Crime-Concentration-and-Hot-Spot-Dynamics-in LatinAmerica.pdf?sequence $=1$.

ALVARADO, Nathalie; MUGGAH, Robert. (2018), “Crimen y violencia: un obstáculo para el desarrollo de las ciudades de América Latina y el Caribe". IDB Working Paper IDBDP-644, vol. 2.

BEALL, Jo; CRANKSHAW, Owen; PARNELL, Susan. (2014), Uniting a divided city: governance and social exclusion in Johannesburg. London: Routledge.

BERGMAN, Marcelo. (2018), More money, more crime: prosperity and rising crime in Latin America. Oxford University Press.

BERNASCO, Win; HENK, Elffers. (2010), "Statistical analysis of spatial crime data”. In: A. R. Piquero; D. Weisburd (eds.), Handbook of quantitative criminology. New York: Springer, pp. 699-724.

BIDERMAN, Ciro; MELLO, João M. P. de; SCHNEIDER, Alexandre. (2009), “Dry laws and homicides: evidence from the São Paulo metropolitan area". The Economic Journal, vol. 120 , no 543, pp. $157-182$.

BOURGUIGNON, Francois; NUNEZ, Jairo; SANCHEZ, Fabio. (2003), “A structural model of crime and inequality in Colombia". Journal of the European Economic Association, vol. 1, no 2-3, pp. 440-449.

BRICEÑO-LEON, Roberto; VILLAVECES, Andrés; CONCHA-EASTMAN, Alberto. (2008), "Understanding the uneven distribution of the incidence of homicide in Latin America". International Journal of Epidemiology, vol. 37, no 4, pp. 75-757.

BUVINIC, Mayra; MORRISON, Andrew R. (2000), "Living in a more violent world". Foreign Policy, no 118 , pp. 58-72.

CALDEIRA, Teresa P. R. (2001), City of walls. Crime, segregation and citizenship in São Paulo. Oakland, University of California Press.

CARDIA, Nancy. (2000), Urban violence in São Paulo. Washington: Woodrow Wilson International Center for Scholars.

CARMONA VILLALOBOS, Keylor; RAMOS ESQUIVEL, Mario A.; SÁNCHEZ MATARRITA, Fernando J. (2005), Dimensión espacial de la pobreza, distribución del Ingreso y polarización social en Costa Rica. PhD Thesis, Universidad de Costa Rica, San José.

CECCATO, Vania. (2005), "Homicides in São Paulo, Brazil: assessing spatial-temporal and weather variations”. Journal of Environmental Psychology, vol. 25, no 3, pp. 307-321.

CECCATO, Vania (ed.). (2012), The urban fabric of crime and fear. Dordrecht: Springer Netherlands.

CECCATO, Vania. (2014), "The geographic, socioeconomic and cultural determinants of violence". In: P. D. Donnelly; C. L. Ward (eds.), Oxford textbook of violence prevention: epidemiology, evidence, and policy. Oxford: Oxford University Press, pp. 77-86. 


\section{Gregorio Gimenez, Liubov Tkacheva, Katarína Svitková and Beatriz Barrado}

CHON, Don Soo. (2011), "Contributing factors for high homicide rate in Latin America: A critical test of Neapolitan's regional subculture of violence thesis". Journal of Family Violence, vol. 26, no 4, p. 299.

COY, Martin; POHLER, Martin. (2002), "Gated communities in Latin American megacities: case studies in Brazil and Argentina". Environment and Planning B: Planning and Design, vol. 29, no 3, pp. 355-370.

COZENS, Paul M. (2007), "Public Health and the potential benefits of crime prevention through environmental design". New South Wales Public Health Bulletin, vol. 18, no $11-12$, pp. 232-237.

. (2011), “Urban planning and environmental criminology: Towards a new perspective for safer cities". Planning Practice and Research, vol. 26, n 4, pp. 481-508.

CURMAN, Andrea S. N.; ANDERSEN, Martin A.; BRANTINGHAM, Paul J. (2015), "Crime and place: a longitudinal examination of street segment patterns in Vancouver, BC". Journal of Quantitative Criminology, vol. 31, no 1, pp. 127-147.

ECK, John E.; WEISBURD, David. (2015), "Crime places in crime theory". Crime and Place: Crime Prevention Studies, vol. 4, pp. 1-33.

FAJNZYLBER, Pablo; LEDERMAN, Daniel; LOAYZA, Norman. (2002), "Inequality and violent crime". The Journal of Law and Economics, vol. 45, no 1, pp. 1-39.

FAY, Marianne (ed.). (2005), The urban poor in Latin America. Washington: The World Bank.

GAVIRIA, Alejandro; VELEZ, Carlos Eduardo. (2001), Who bears the burden of crime in Colombia?. Retrieved from https://ssrn.com/abstract=256746.

GAVIRIA, Alejandro; PAGÉS, Carmen. (2002), "Patterns of crime victimization in Latin American cities". Journal of Development Economics, vol. 67, no 1, pp. 181-203.

GILL, Charlotte; WOODITCH, Alese; WEISBURD, David. (2017), “Testing the 'Law of Crime at Place' in a suburban setting: Implications for research and practice". Journal of Quantitative Criminology, vol. 33, n 3, pp. 519-545.

GLAESER, Edward L.; SACERDOTE, Bruce. (1999), “Why is there more crime in cities?". Journal of Political Economy, vol. 107, n⿳은, pp. 225-258.

GOLDSMITH, Victor; McGUIRE, Philip G. (2000), Analysing crime patterns: frontiers of practice. London: Sage Publications.

GRAIF, Corina; GLADFELTER, Andrew S.; MATTHEWS, Stephen A. (2014), “Urban poverty and neighborhood effects on crime: Incorporating spatial and network perspectives". Social Compass, vol. 8, no 9, pp. 1140-1155.

HARROFF-TAVEL, Marion. (2010), "Violence and humanitarian action in urban areas: new challenges, new approaches. Humanitarian debate: Law, policy, action". Urban Violence. International Review of the Red Cross, vol. 92, no 878, pp. 329-351.

HUMAN SECURITY IN CITIES. (2007), Human Security for an Urban Century. Local Challenges, Global Perspectives. Retrieved from https://docs.unocha.org/sites/dms/HSU/ human_security_for_an_urban_century $\% 20$ South $\% 20$ America $\% 20 \% 281 \% 29$.pdf. 
INTER-AMERICAN DEVELOPMENT BANK (IDB). (2013), Análisis de los homicidios en seis países de América Latina. Documento de debate IDB-DP-302. Washington: Inter-American Development Bank.

. (2017), Los costos del crimen y la violencia: nuevas evidencias y percepciones en América Latina y el Caribe. Washington: Inter-American Development Bank.

JAITMAN, Laura; GUERRERO COMPEAN, Roberto. (2015), Closing knowledge gaps: toward evidence-based crime prevention policies in Latin America and the Caribbean. Washington: Inter-American Development Bank.

JOHNSON, Shane D.et al. (2007), "Spacetime patterns of risk: A cross national assessment of residential burglary victimization". Journal of Quantitative Criminology, vol. 23, nº 3, pp. 201-219.

JURGENS, Ulrich; GNAD, Martin. (2002), "Gated communities in South Africa: experiences from Johannesburg”. SAGE Journals, vol. 29, no 3, pp. 337-353.

JÜTERSONKE, Oliver; MUGGAH, Rober; RODGERS, Dennis. (2009), “Gangs, urban violence and security interventions in Central America". Security Dialogue, vol. 40, no 4-5, pp. 373-397.

LANDMAN, Karina. (2012), "Reconsidering crime and urban fortification in South Africa". In: V. Ceccato (ed.), The urban fabric of crime and fear. Dordrecht: Springer Netherlands, pp. 239-264.

LAPPI-SEPPALA, Tapio; LEHTI, Martti. (2014), “Cross-comparative perspectives on global homicide trends". Crime and Justice, vol. 43, nº 1, pp. 135-230.

LUALLEN, Jeremy. (2006), “School's out... forever: A Study of juvenile crime, at-risk youths and teacher strikes". Journal of Urban Economics, vol. 59, no 1, pp. 75-103.

MARTÍNEZ JR., Ramiro; ROSENFELD, Richard; MARES, Dennis. (2008), “Social disorganization, drug market activity, and neighborhood violent crime". Urban Affairs Review, vol. $43, n^{\circ} 6$, pp. $846-874$.

MATUTE, Arturo; GARCÍA, Iván. (2007), Guatemala. Unpublished paper. Geneva, Small Arms Survey.

MINISTERIO DE SALUD; ORGANIZACIÓN PANAMERICANA DE LA SALUD. (2004), La violencia social en Costa Rica. San José: Ministerio de Salud.

MUGGAH, Robert. (2012), Researching the Urban Dilemma. Urbanization, Poverty and Violence. Canada: International Development Research Center.

NEWMAN, Oscar. (1996), Creating defensible space. Darby, Diane Publishing. Retrieved from http:/ / www.huduser.gov/publications/pdf/def.pdf.

PROGRAMA DE LAS NACIONES UNIDAS PARA EL DESARROLLO (PNUD). (2013), Informe regional del desarrollo humano: diagnóstico y propuestas para América Latina. New York: United Nations Development Program. 


\section{Gregorio Gimenez, Liubov Tkacheva, Katarína Svitková and Beatriz Barrado}

RATCLIFFE, Jerry. (2010), “Crime mapping. Spatial and temporal challenges”. In: A. R. Piquero; D. Weisburd (eds.), Handbook of quantitative criminology. New York: Springer, pp. 5-24.

RIVERA, Mauricio. (2016), "The sources of social violence in Latin America: an empirical analysis of homicide rates, 1980-2010". journal of peace research, vol. 53, no 1, pp. 84-99.

RODGERS, Dennis. (2004), “'Disembedding' the city: crime, insecurity and spatial organization in Managua, Nicaragua". Environment and Urbanization, vol. 16, no 2, pp. 113-124.

SAMPSON, Robert J.; RAUDENBUSH, Stephen W. (2001), Disorder in urban neighborhoods: does it lead to crime? Washington: US Department of Justice, Office of Justice Programs, National Institute of Justice.

SAMPSON, Robert J.; RAUDENBUSH, Stephen W.; EARLS, Felton. (1997), “Neighborhoods and violent crime: A multilevel study of collective efficacy". Science, vol. 277, nº 5328, pp. 918-924.

SASSEN, Saskia. (2006), Territory, authority, rights: from medieval to global assemblages. Princeton: Princeton University Press.

SHAW, Clifford R.; MCKAY, Henry D. (1942), Juvenile delinquency and urban areas. Chicago: University of Chicago Press.

SHOFF, Carla; YANG, Tse-Chuan. (2012), "Untangling the associations among distrust, race, and neighborhood social environment: a social disorganization perspective". Social Science \& Medicine, vol. 74, no 9, pp. 1342-1352.

SOARES, Rodrigo R. (2004), "Development, crime and punishment: accounting for the international differences in crime rates". Journal of Development Economics, vol. 73, $\mathrm{n}^{\mathrm{N}} 1$, pp. 155-184.

SOARES, Rodrigo R.; NARITOMI, Joana. (2010), “Understanding high crime rates in Latin America: the role of social and policy factors". In: R. Di Tella; S. Edwards; E. Schargrodsky (eds.),

The economics of crime: lessons for and from Latin America. Chicago: University of Chicago Press, pp. 19-55.

UN-HABITAT. (2007), Enhancing urban safety and security. Global Report on Human Settlements. London: Earthscan.

UN-HABITAT. (2012), The State of Latin American and Caribbean Cities 2012. Towards a new urban transition. Nairobi: UN-Habitat.

UNIDAD DE INFORMACION Y ESTADISTICA NACIONAL SOBRE DROGAS DEL INSTITUTO COSTARRICENSE SOBRE DROGAS. (2018), Informe de Situación Nacional sobre Drogas y Actividades Conexas. Costa Rica 2017. San José: Costa Rica.

UNITED NATIONS OFFICE ON DRUGS AND CRIME (UNODC). (2014), Global Study on Homicide 2013. UNODC, Vienna. p. 166.

. (2019), Statistical Database. UNODC.

DADOS, Rio de Janeiro, vol.64 (1): e20190127, 2021 
VILALTA PERDOMO, Carlos. J.; CASTILLO, José. G.; TORRES, Juan. A. (2016), “Delitos violentos en ciudades de América Latina". Working Paper number IDB-DP-474. Washington, Banco Interamericano de Desenvolvimento.

WEISBURD, David L. (2015), "The law of crime concentration and the criminology of place". Criminology, vol. 53, no 2, pp. 133-157.

; AMRAM, Shai. (2014), "The law of concentrations of crime at place: The case of Tel Aviv-Jaffa". Police Practice and Research, vol. 15, no 2, pp. 101-114.

WOOLDRIDGE, Jeffrey M. (1995), “Score diagnostics for linear models estimated by two stage least squares". In: G. S. Maddala; P. C. B. Phillips; T. N. Srinivasan (eds.), Advances in econometrics and quantitative economics: essays in honor of Professor C. R. Rao. Oxford: Blackwell, pp. 66-87.

WORLD BANK. (2011a), Making Room for a Planet of Cities. World Bank, 03.02.2011. Retrieved from https://www.worldbank.org/en/news/press-release/2011/01/27/making-room-for-a-planet-of-cities_

. (2011b), Violence in the City. Understanding and Supporting Community Responses to Urban Violence. Washington: World Bank. 


\section{APPENDIX}

Table A.1

List of variables, sources and summary statistics

\begin{tabular}{|c|c|c|c|c|c|}
\hline Variable & Definition & Source & Year & Mean & S.d. \\
\hline $\begin{array}{l}\text { Annual popu- } \\
\text { lation growth }\end{array}$ & Annual population growth. & INEC & $\begin{array}{l}\text { Between } \\
2000 \text { and } \\
2011\end{array}$ & 0.010 & 0.018 \\
\hline $\begin{array}{l}\text { Attack (non- } \\
\text { residential } \\
\text { building) }\end{array}$ & $\begin{array}{l}\text { Attack with violence in } \\
\text { which an individual takes } \\
\text { property for personal use, } \\
\text { such as goods or money, } \\
\text { from a building, without } \\
\text { the owner's permission. Per } \\
\text { every } 10,000 \text { inhabitants. }\end{array}$ & OIJ and INEC & $\begin{array}{l}\text { Average } \\
\text { value } \\
2010-2013\end{array}$ & 6.210 & 16.540 \\
\hline $\begin{array}{l}\text { Attack } \\
\text { (residential } \\
\text { building) }\end{array}$ & $\begin{array}{l}\text { Attack with violence in } \\
\text { which an individual takes } \\
\text { property for personal use, } \\
\text { such as goods or money, } \\
\text { from someone else's house, } \\
\text { without the owner's per- } \\
\text { mission. Per every } 10,000 \\
\text { inhabitants. }\end{array}$ & OIJ and INEC & $\begin{array}{l}\text { Average } \\
\text { value } \\
2010-2013\end{array}$ & 5.399 & 5.537 \\
\hline $\begin{array}{l}\text { Average } \\
\text { schooling } \\
\text { years +15 }\end{array}$ & $\begin{array}{l}\text { Average years of education } \\
\text { completed by persons } 15 \\
\text { years and over with respect } \\
\text { to the population } 15 \text { years } \\
\text { and over. }\end{array}$ & INEC and IGN & 2011 & 7.981 & 1.623 \\
\hline Gini index & Gini index. & CRS & 2005 & 0.412 & 0.043 \\
\hline Homicide rate & $\begin{array}{l}\text { Intentional homicide, that } \\
\text { is, a homicide in which } \\
\text { the criminal intentionally } \\
\text { seeks the victim's death. Per } \\
\text { every } 10,000 \text { inhabitants. }\end{array}$ & OIJ and INEC & $\begin{array}{l}\text { Average } \\
\text { value } \\
2010-2013\end{array}$ & 0.777 & 1.042 \\
\hline Immigrants & $\begin{array}{l}\text { Percentage of the popula- } \\
\text { tion not born in the country. }\end{array}$ & INEC and IGN & 2011 & 0.021 & 0.018 \\
\hline Men & Ratio of men to women. & INEC and IGN & 2011 & 0.498 & 0.019 \\
\hline
\end{tabular}


Table A.1

List of variables, sources and summary statistics (cont.)

\begin{tabular}{|c|c|c|c|c|c|}
\hline Variable & Definition & Source & Year & Mean & S.d. \\
\hline Mugging & $\begin{array}{l}\text { Crime characterized by } \\
\text { a violent attack on an } \\
\text { individual, usually with } \\
\text { the objective of robbery. Per } \\
\text { every } 10,000 \text { inhabitants. }\end{array}$ & OIJ and INEC & $\begin{array}{l}\text { Average } \\
\text { value } \\
2010-2013\end{array}$ & 14.030 & 46.350 \\
\hline Police force & $\begin{array}{l}\text { Police paid by the state, and } \\
\text { depending on Costa Rica's } \\
\text { Ministerio de Seguridad. } \\
\text { Per every } 1,000 \text { inhabitants. }\end{array}$ & INEC and MSP & 2011 & 4.025 & 2.541 \\
\hline $\begin{array}{l}\text { Population } \\
\text { density }\end{array}$ & $\begin{array}{l}\text { The original variable is } \\
\text { defined as the average } \\
\text { population of a district per } \\
\text { square kilometre. How- } \\
\text { ever, regressions show the } \\
\text { figures multiplied by 1,000 } \\
\text { for readability. }\end{array}$ & INEC and IGN & 2011 & 1,186 & 2,359 \\
\hline $\begin{array}{l}\text { Poverty index } \\
\text { (unsatisfied } \\
\text { basic needs) }\end{array}$ & $\begin{array}{l}\text { Percentage of households } \\
\text { having at least one unsatis- } \\
\text { fied basic need (in shelter, } \\
\text { hygiene, education or } \\
\text { consumption), }\end{array}$ & INEC and IGN & 2011 & 0.314 & 0.145 \\
\hline $\begin{array}{l}\text { Robbery (non } \\
\text { residential } \\
\text { building) }\end{array}$ & $\begin{array}{l}\text { The seizure of another's } \\
\text { assets from a building, with } \\
\text { the intention of profiting, } \\
\text { employing force, violence } \\
\text { or intimidation. Per every } \\
10,000 \text { inhabitants. }\end{array}$ & OIJ and INEC & $\begin{array}{l}\text { Average } \\
\text { value } \\
2010-2013\end{array}$ & 11.840 & 11.750 \\
\hline $\begin{array}{l}\text { Robbery } \\
\text { (people) }\end{array}$ & $\begin{array}{l}\text { The seizure of another's } \\
\text { assets with the intention of } \\
\text { profiting, employing force, } \\
\text { violence or intimidation. } \\
\text { Per every 10,000 inhabit- } \\
\text { ants. }\end{array}$ & OIJ and INEC & $\begin{array}{l}\text { Average } \\
\text { value } \\
2010-2013\end{array}$ & 0.690 & 1.467 \\
\hline
\end{tabular}


Table A.1

List of variables, sources and summary statistics (cont.)

\begin{tabular}{|c|c|c|c|c|c|}
\hline Variable & Definition & Source & Year & Mean & S.d. \\
\hline $\begin{array}{l}\text { Robbery } \\
\text { (residential } \\
\text { building) }\end{array}$ & $\begin{array}{l}\text { The seizure of another's } \\
\text { assets from a house, with } \\
\text { the intention of profiting, } \\
\text { employing force, violence } \\
\text { or intimidation. Per every } \\
10,000 \text { inhabitants. }\end{array}$ & OIJ and INEC & $\begin{array}{l}\text { Average } \\
\text { value } \\
2010-2013\end{array}$ & 15.620 & 12.940 \\
\hline $\begin{array}{l}\text { Robbery or } \\
\text { theft of items } \\
\text { in vehicles }\end{array}$ & $\begin{array}{l}\text { Offense consisting of rob- } \\
\text { bing or stealing objects from } \\
\text { a motor vehicle, whether or } \\
\text { not locked. Per every 10,000 } \\
\text { inhabitants. }\end{array}$ & OIJ and INEC & $\begin{array}{l}\text { Average } \\
\text { value } \\
2010-2013\end{array}$ & 7.784 & 14.730 \\
\hline $\begin{array}{l}\text { Theft (non- } \\
\text { residential } \\
\text { building) }\end{array}$ & $\begin{array}{l}\text { The perpetrator takes } \\
\text { something from a building } \\
\text { unlawfully with the inten- } \\
\text { tion of keeping it. Per every } \\
10,000 \text { inhabitants. }\end{array}$ & OIJ and INEC & $\begin{array}{l}\text { Average } \\
\text { value } \\
2010-2013\end{array}$ & 2.045 & 4.094 \\
\hline Theft (people) & $\begin{array}{l}\text { A form of theft in which an } \\
\text { individual takes property } \\
\text { for personal use, such as } \\
\text { goods or money, without } \\
\text { the owner's permission. Per } \\
\text { every } 10,000 \text { inhabitants. }\end{array}$ & OIJ and INEC & $\begin{array}{l}\text { Average } \\
\text { value } \\
2010-2013\end{array}$ & 13.340 & 51.880 \\
\hline $\begin{array}{l}\text { Theft (residen- } \\
\text { tial building) }\end{array}$ & $\begin{array}{l}\text { The perpetrator takes } \\
\text { something from someone's } \\
\text { house illegally with the } \\
\text { intention of keeping it. Per } \\
\text { every 10,000 inhabitants. }\end{array}$ & OIJ and INEC & $\begin{array}{l}\text { Average } \\
\text { value } \\
2010-2013\end{array}$ & 1.223 & 1.508 \\
\hline $\begin{array}{l}\text { Unemploy- } \\
\text { ment rate }\end{array}$ & Unemployment rate. & INEC and IGN & 2011 & 0.031 & 0.012 \\
\hline
\end{tabular}


Table A.1

List of variables, sources and summary statistics (cont.)

\begin{tabular}{|c|c|c|c|c|c|}
\hline Variable & Definition & Source & Year & Mean & S.d. \\
\hline $\begin{array}{l}\text { Urban } \\
\text { population }\end{array}$ & $\begin{array}{l}\text { Percentage of the popula- } \\
\text { tion of a district living } \\
\text { in an urban area. Urban } \\
\text { areas were defined a priori } \\
\text { by Instituto Nacional de } \\
\text { Estadistica y Censos with } \\
\text { physical and functional } \\
\text { criteria, taking into account } \\
\text { tangible items such as } \\
\text { clearly defined quadrants, } \\
\text { streets, sidewalks, urban } \\
\text { services (garbage collec- } \\
\text { tion, street lighting) and } \\
\text { economic activities. The } \\
\text { administrative centres of } \\
\text { each county or district } \\
\text { performed geographic } \\
\text { delineation. }\end{array}$ & INEC and IGN & 2011 & 0.523 & 0.377 \\
\hline Vehicle theft & $\begin{array}{l}\text { Offense consisting of the } \\
\text { seizure of another's vehicle } \\
\text { with the intention of profit- } \\
\text { ing, employing force, vio- } \\
\text { lence or intimidation. Per } \\
\text { every } 10,000 \text { inhabitants. }\end{array}$ & OIJ and INEC & $\begin{array}{l}\text { Average } \\
\text { value 2010- } \\
2013\end{array}$ & 7.531 & 8.801 \\
\hline
\end{tabular}

Sources: CRS: Carmona; Ramos and Sánchez (2005); IGN: Instituto Geográfico Nacional; INEC: Instituto Nacional de Estadística y Censos; MSP: Ministerio de Seguridad Pública; OIJ: Organismo de Investigación Judicial. 


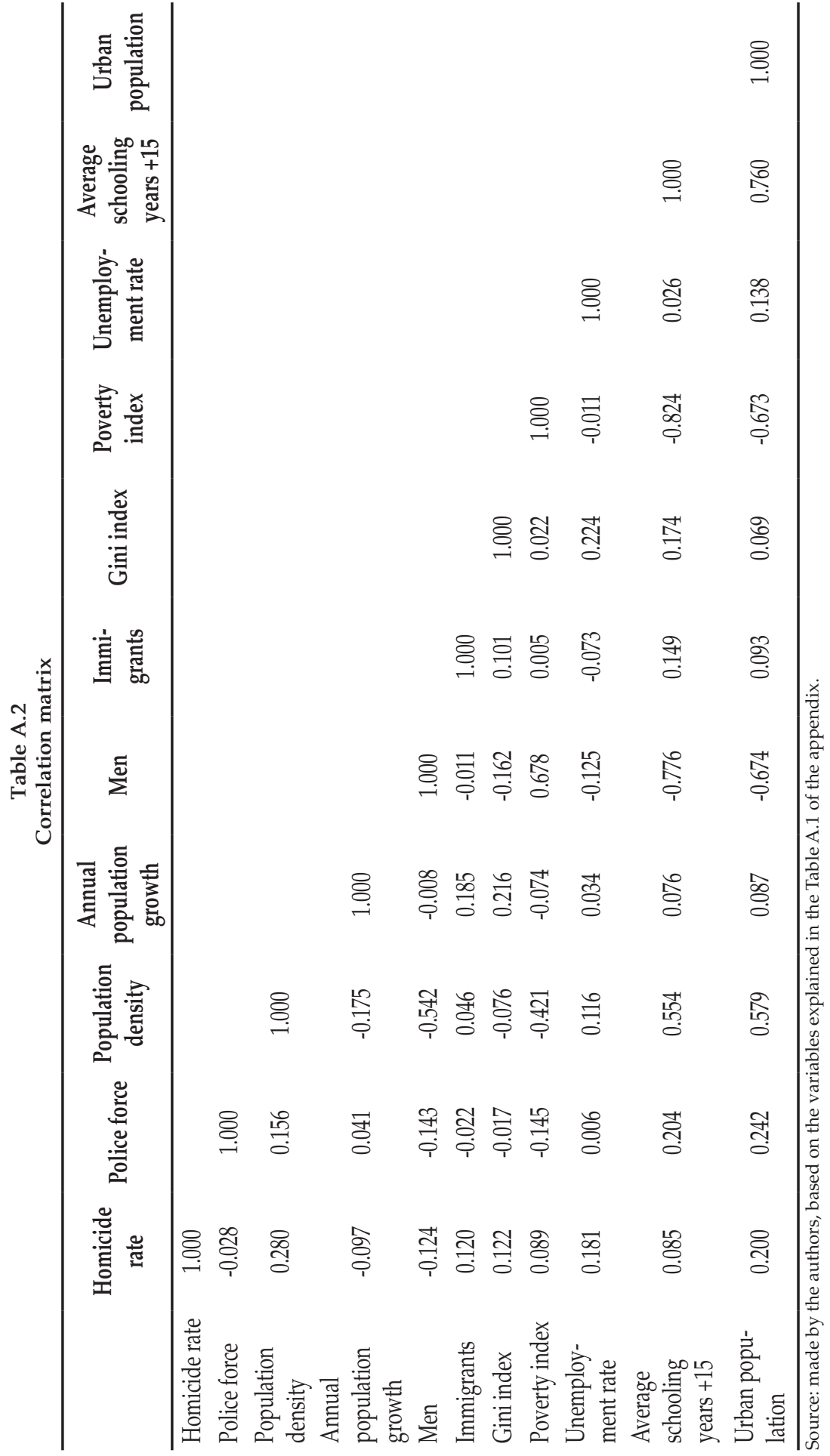




\section{RESUMO \\ Cidades e Violência: Uma Análise Empirica do Caso de Costa Rica}

Este artigo foca no efeito da urbanização no que tange a crimes violentos - particularmente homicídios - na Costa Rica. Apesar de a violência ser um grave problema em toda a América Latina, poucos estudos empíricos conduzidos nessa área usam bancos de dados socioeconômicos e de criminalidade de alta qualidade, com alto nível de desagregação geográfica. Neste artigo, empregamos dados de todos os 473 distritos de Costa Rica entre 2010 e 2013. Desenvolvemos um modelo que leva em consideração problemas de endogeneidade e usa contrastes de predições lineares marginais. Concluímos que o grau de concentração urbana desempenha um papel determinante na explicação de taxas de homicídio, mantendo constantes as demais variáveis. Esse efeito é progressivo: quanto maior a concentração urbana, maiores são as taxas de homicídio. Essa relação causal não é observada em outros crimes.

Palavras-chave: crime; violência; urbano; cidades; América Latina; Costa Rica

\section{ABSTRACT \\ Cities and Violence: An Empirical Analysis of the Case of Costa Rica}

This article focuses on the effect of urbanization on violent crime - particularly homicide in Costa Rica. Although violence is a major problem throughout Latin America, few empirical studies carried out in the area use high-quality socioeconomic and crime databases with a high level of geographical disaggregation. In this article, we employ data from all 473 districts of Costa Rica between 2010 and 2013. We develop a model which takes into account endogeneity problems and uses contrasts of marginal linear predictions. We conclude that the degree of urban concentration plays a key role in explaining homicide rates, other things being equal. This effect is progressive: the greater the urban concentration, the greater the increase in homicide rates. This causal relationship is not observed in offenses other than homicide.

Keywords: crime; violence; urban; cities; Latin America; Costa Rica 


\title{
Gregorio Gimenez, Liubov Tkacheva, Katarína Svitková and Beatriz Barrado
}

\author{
RÉSUMÉ \\ Villes et Violence: Une Analyse Empirique du Cas du Costa Rica
}

Cet article se concentre sur l'effet de l'urbanisation sur la criminalité violente - en particulier l'homicide au Costa Rica. Bien que la violence soit un problème majeur dans toute l'Amérique Latine, peu d'études empiriques menées dans la région utilisent des bases de données socio-économiques et criminelles de haute qualité avec un niveau élevé de désagrégation géographique. Dans cet article, on utilise les données des 473 districts du Costa Rica entre 2010 et 2013. On développe un modèle qui prend en compte les problèmes d'endogénéité et utilise des contrastes de prédictions linéaires marginales. On conclut que le degré de concentration urbaine joue un rôle clé dans l'explication des taux d'homicides, toutes choses étant égales par ailleurs. Cet effet est progressif: plus la concentration urbaine est élevée, plus l'augmentation des taux d'homicides est importante. Cette relation de cause à effet n'est pas observée dans les infractions autres que l'homicide.

Mots-clés: crime; violence urbaine; villes; Amérique Latine; Costa Rica

\section{RESUMEN \\ Ciudades y Violencia: Un Análisis Empírico del Caso de Costa Rica}

Este artículo se centra en analizar el efecto de la urbanización en los delitos violentos - particularmente el homicidio en Costa Rica. Aunque la violencia es un problema generalizado a lo largo de América Latina, pocos estudios realizados en esta área usan bases de datos socioeconómicas y de criminalística con un alto nivel de segregación geográfica. En este artículo, utilizamos datos de los 473 distritos de Costa Rica entre 2010 y 2013, para lo cual desarrollamos un modelo que tome en cuenta los problemas de endogeneidad y que utilice contrastes de predicciones lineares marginales. Concluimos que el grado de concentración urbana juega un papel fundamental para explicar las tasas de homicidio, en igualdad de otras condiciones. Este efecto es progresivo: cuanto mayor es la concentración urbana, mayor es el aumento de las tasas de homicidio. Esta relación de causalidad no se observa en delitos distintos al homicidio.

Palabras clave: crimen; violencia; urbano; ciudades; América Latina; Costa Rica 